\author{
Piotr Niczyporuk \\ University in Bialystok, Poland \\ ORCID: 0000-0002-2240-0959 \\ p.niczyporuk@uwb.edu.pl
}

\title{
Penal Sanctions Applicable to a Slave Engaged in Banking Activities
}

\author{
Sankcje karne zastosowane wobec niewolnika zajmującego się \\ działalnością bankierską
}

\section{SUMMARY}

Gaius Suetonius in Vitae Galbae, as part of his Vita divi Augusti, described the case of a banker (nummularius) and the penal sanction applied to him by the later emperor Galba. The governor of the province of Hispania Tarraconensis ordered to cut off the hands of a banker who was unfairly changing money. In order to show even greater severity of the punishment, he ordered the cut off hands to be nailed to the table where the banker was performing the dishonest acts. Undoubtedly, nummularius punished by Galba conducted operations within mensa nummularia. The owners of the cantors used qualified people recruited from among the lower social strata, mainly slaves, to perform mint operations. The professional examination of the quality of a coin required a great deal of specialist work. The convict participated in the banking activity as a support technical personnel. The minting and testing operations ended with sealing the purse with tesserae nummulariae. Such specialized operations were not performed by Roman citizens. The content of tesserae nummulariae may be an indication that the testing operations were performed by slaves. Servi had actual knowledge of the contents of the controlled purses and the control process could be an opportunity for abuse or even punishable acts. The slave would therefore suffer a well-deserved and adequate punishment in the form of chopping off his hands and nailing them to the table at which he dishonestly carried out minting and testing activities.

Keywords: Galba; banker; nummularius; lex; slave; mutilation; mutilatio; mensa nummularia; money change; coin quality; minting operations; coin value 
Since the third century BC, a social and economic development has been observed and linked to the numerous Roman conquests in the Mediterranean basin ${ }^{1}$. As trade, transport and crafts flourished, banking and financial activity increased. New social strata were formed, in particular the new aristocracy (nobilitas) and rich entrepreneurs, merchants or bankers ${ }^{2}$.

Gaius Suetonius Tranquillus in Vita divi Augusti described the case of a banker (nummularius) and the penal sanction applied to him by the later Emperor Galba ${ }^{3}$. The aim of this paper is to take a new look at the excerpt of Vitae Galbae quoted below in attempt to indicate a few arguments for recognizing that the historian's description and the punishment referred to the slave.

Suet., Vita Galbae 9. Per octo annos varie et inaequabiliter provinciam rexit, primo acer et vehemens et in coercendis quidem delictis vel immodicus. Nam et nummulario non ex fide versanti pecunias manus amputavit mensaeque eius adfixit, et tutorem, quod pupillum, cui substitutus heres erat, veneno necasset, cruce adfecit; implorantique leges et civem Romanum se testificanti, quasi solacio et honore aliquo poenam levaturus, mutari multoque praeter ceteras altiorem et dealbatam statui crucem iussit. Paulatim in desidiam segnitiemque conversus est, ne quid materiae praeberet Neroni, et ut dicere solebat, quod nemo rationem otii sui reddere cogeretur ${ }^{4}$.

1 G. Alföldi, Historia społeczna starożytnego Rzymu, Poznań 1998, p. 62.

2 R.H. Chico, Función y origen de los 'Argentarii', "Anuario de Estudios Sociales y Juridicos" 1977, no. 6, p. 105 ff.; J. Andreau, Financiers de l'aristocratie à la fin de la République romaine, [in:] Le dernier siècle de la Republique romaine et l'époque augustéenne, Strasbourg 1978, pp. 47-62; idem, La vie financière dans le monde romain. Les métiers des maniers d'argent (IV e siècle au J.C. - III e siècle ap. J.C.), Roma 1987, p. 5 ff.; idem, Les comtes bancaires en nature, «Index » 1987, no. 15, p. 413 ff.; G. Maselli, 'Argentaria'. Banche e banchieri nella Roma repubblicana. Organizzazione prosopografia terminologia, Bari 1986, passim; A. Bürge, Fiktion und Wirklichkeit: Soziale und rechtliche Strukturen des römischen Bankwesens, „ZSS“ 1987, no. 104, p. 463 ff.; M.A. Peńalver Rodriguez, La banca en Roma, [in:] Estudos en Homenaje al Profesor Juan Igliesias, eds. J. Roset Esteve, J. Iglesias Santos, vol. 3, Madrid 1988, p. 1531 ff.; A. Petrucci, 'Mensam exercere'. Studi sull'impresa finanziaria romana (II sec. a. C. - età del III sec. d.C.), Napoli 1991, p. 6 ff.; idem, Qualche riflessione sulla possibile configurazione di un 'diritto bancario' romano nell'età commerciale (età del III secolo a.C. - età del III secolo d.C.), "Studi Senesi" 2005, no. 15, pp. 71-85; P. Niczyporuk, A. Talecka, Rzymska antyczna bankowość wspólnym dziedzictwem Europy, [in:] Pieniadz-symbol-władza-wojna - wspólne dziedzictwo Europy, Białoruś-Estonia-Litwa- - otwa-Polska-Rosja-Rumunia-Stowacja-Ukraina, Studia i materiały, ed. K. Filipow, Augustów-Warszawa 2010, p. 28 ff.; P. Niczyporuk, Bankierzy i operacje bankierskie w starożytnym Rzymie, Białystok 2013, p. 14.

3 Cf. P. Niczyporuk, Kilka uwag o karze mutylacyjnej wykonanej wobec rzymskiego bankiera (na marginesie Vita Galbae 9), „Zeszyty Prawnicze” 2019, no. 19.1, pp. 103-115.

4 Galba 9. "For eight years he governed the province in a variable and inconsistent manner. At first he was vigorous and energetic and even over severe in punishing offences; for he cut off the hands of a money-lender who carried on his business dishonestly and nailed them to his counter; crucified a man for poisoning his ward, whose property he was to inherit in case of his death; and when the man invoked the law and declared that he was a Roman citizen, Galba, pretending to lighten his punishment by some consolation and honour, ordered that a cross much higher than the rest and painted white be set up, and the man transferred to it" (Suetonius, Lives of the Twelve Caesars, Servius Sulpicius Galba, transl. H.M. Bird, Kent 1997, pp. 286-287). 
The historian gave an account of the administration of the province of Hispania Tarraconensis by the later emperor Galba in the years 60 to 68 AD. Suetonius drew attention to the negative character traits of the provincial governor (praeses provinciae), namely variability and capriciousness, which resulted in quite controversial punishments issued by the future emperor. Galba ordered to cut off the hands of the banker (nummularius) who dishonestly changed money. In order to show even greater severity of the punishment, he ordered the cut off hands to be nailed to the table on which this banker performed fraudulent operations.

Suetonius' statement about a person involved in banking activity may raise some doubts of interpretation. Undoubtedly, nummularius punished by Galba conducted operations within mensae nummulariae. The fragmentary nature of the message does not make it possible to clearly state whether he acted as an institutor, exercitor, or maybe he was only a person actually performing financial operations.

In the facts presented by Suetonius, we have two cases of conviction and execution of the sentence, namely the mutilation (mutilatio) applied to nummularii and the crucifixion ${ }^{5}$. In the latter, we are dealing with a Roman citizen, which may suggest that the punishment of cutting off (chopping off) hands affected a person of a lower social status or even a slave. Probably this civis Romanus also did not belong to the category of ingenui, but was only a freedman. Moreover, person sentenced to crucifixion committed murder, an act threatened with the highest criminal sanction. The execution of both penalties at the same time may raise some doubts. Unquestionably, both penal sanctions applied by the later emperor Galba had a common, eastern origin ${ }^{6}$ and served to disgrace the convict. Therefore, it

5 Crucifixion (crucifixio) was used primarily against slaves, foreigners, and a citizen with a lower social status could thus be punished for banditry, piracy, desertion, rape, or street riots. The punishment was known and applied in the ancient world, especially in the Eastern despots. Also the punishment of depriving the convicted person of particular parts of his or her body was provided for in the Hammurabi Code. The penal sanction of deprivation of hand ( $\S 195,218,226,253)$, stabbing the eye (§ 193), cutting off the ear ( $§ 282)$ or cutting off the tongue ( $(192)$ was used in ancient Mesopotamia. In turn, in Torah there were also known punishments consisting in cutting off the hand (Deut. 25, 11-12: "If men, a man and his brother, are fighting together, and the wife of one of them approaches to rescue her husband from his assailant, and she stretches forth her hand and grabs hold of his private parts you shall cut off her hand you shall not have pity"). Sanctions consisting of depriving the convicted person of particular parts of his or her body were applied during the period of existence of the Persian Saxonites. See M. Jońca, Przestępstwo znieważenia grobu w rzymskim prawie karnym, Lublin 2013, p. 329; P. Niczyporuk, Kilka uwag o karze mutylacyjnej..., p. 105.

6 More on the matter: R. Taubenschlag, Rzymskie prawo prywatne na tle praw antycznych, Warszawa 1955, p. 13. Cf. T. Maciejewski, Historia powszechna ustroju i prawa, Warszawa 2007, pp. 62-65; K. Sójka-Zielińska, Drogi i bezdroża prawa, Wrocław 2000, p. 18; D.H. Müller, Die Gesetze Hammurabis und ihr Verhältnis zur Mosaischen Gesetzgebung, sowie zu den XII Tafeln, Wien 1903, p. 146 ff.; R. Westbrook, Studies in Biblical and Cuneiform Law, Paris 1988, pp. 39-126; L. Fijałkowska, O przydatności mediewistyki prawniczej dla studiów nad historia prawa starożytnego Bliskiego Wschodu, „Studia z Dziejów Państwa i Prawa Polskiego” 2009, no. 12, p. 46; D. Nowicka, 
would be right to apply them to people standing at the bottom of the social ladder. Perhaps both convicts had some sort of eastern origin and that is why the provincial governor decided on such a penalty. An eventuality like this can be taken into account in view of the location of the province of Hispania Tarraconensis ruled by Galba. Many slaves in the Spanish Roman provinces of the early Empire came from Africa and Asia Minor ${ }^{7}$. However, because of the fragmented nature of the source material, this concept must remain only a hypothesis.

The historian's account, however, does not indicate the social status of a person who was punished by cutting (chopping) off his hands. Thus, the question arises as to why it was applied to a banker and what place he held in the social hierarchy in ancient Rome.

Since the ancient Romans knew and applied a wide range of very severe forms of mutilation, often combined with the humiliation of the convicted person and imposed on the lower classes and slaves, it seems that the mutilation applied by Galba could also have a similar social resonance.

In the period of the decline of the Roman Republic and the beginning of the principality, trade and financial activities were an important source of income for the social elite. Banking activities also benefited the upper classes of society. However, a high-ranking person did not conduct commercial or banking business in person, but through slaves, freedmen, clients or other parties, known as amici $i^{8}$.

Within the business activity (in the broadest sense of the term), the work and skills of slaves in the area of property management and financial administration were used primarily. It was the servi who often managed the commercial outlets as well as acted as supervisors of the owner's capital. Slaves thus played an important role in organizing and conducting business ${ }^{9}$ and were very useful in providing creditors with legal mechanisms for effective redress directly from their masters. In addition, the servi had the ability to perform acts leading to property gains for the benefit of their family superior ${ }^{10}$. This authenticated persons acting on behalf of others and provided a guarantee of safe trading ${ }^{11}$.

\footnotetext{
S. Nowicki, Prawo boskie i prawo ludzkie. Sadownictwo starożytnego Izraela na tle praktyki mezopotamskiej, „Scripta Biblica et Orientalia” 2009, no. 1, p. 161, n. 34; K.D. Ryś, Historia kary śmierci do końca I połowy XX wieku. Wybrane zagadnienia, „Kortowski Przegląd Prawniczy” 2012, no. 1, p. 68; W. Kamacewicz, Instytucja kary śmierci od starożytności po średniowiecze - wybrane kraje i kodyfikacje, „Kortowski Przegląd Prawniczy” 2017, no. 2, p. 68; M. Jońca, op. cit., p. 329.

7 J. Mangas Manjarrés, Esclavos y libertos en la España romana, Salamanca 1971, p. 181 ff.; S.J. Keay, Roman Spain, California 1988, p. 98.

8 J. Krzynówek, Odpowiedzialność przedsiębiorcy (exercitor) w prawie rzymskim, Warszawa 2000, p. 16.

9 M. Pawlak, Niewolnicy prywatni w rzymskiej Afryce w okresie wczesnego Cesarstwa, Wrocław 2002, p. $55 \mathrm{ff}$.

${ }_{10}$ J. Andreau, La vie financière..., p. 19.

11 J. Krzynówek, op. cit., p. 18.
} 
The concept presented above, according to which people from lower social strata were involved in banking activities within the framework of mensae nummulariae is illustrated by an excerpt from Scaevola's Digests.

D. 14,3, 20 (Scaevola libro quinto digestorium): Per octo annos varie et inaequabiliter provinciam rexit, primo acer et vehemens et in coercendis quidem delictis vel immodicus. Nam et nummulario non ex fide versanti pecunias manus amputavit mensaeque eius adfixit, et tutorem, quod pupillum, cui substitutus heres erat, veneno necasset, cruce adfecit; implorantique leges et civem Romanum se testificanti, quasi solacio et honore aliquo poenam levaturus, mutari multoque praeter ceteras altiorem et dealbatam statui crucem iussit. Paulatim in desidiam segnitiemque conversus est, ne quid materiae praeberet Neroni, et ut dicere solebat, quod nemo rationem otii sui reddere cogeretur ${ }^{12}$.

The facts presented by the jurist describe the organizational structure of a bank exchange office. At the bottom of the ladder in mensa nummularia there was a freedman who actually conducted banking operations. Above him, there was his patron, to whom, as it results from the content of the quoted source, other nummularii were also subordinated who acted as institutores. Within the framework of the discussed facts, we can indicate a freedman acting as an exercitor, i.e. a person conducting financial activities in his own name and at his own risk ${ }^{13}$. Since libertinus directed mensa nummularia, there were undoubtedly also slaves in the organizational structure of the bank cantor, who actually conducted banking operations on his behalf. There have also been known cases of bankers using servorum petulantium who followed a reluctant debtor in order to force him to return the claim ${ }^{14}$.

It is evidenced by sources that slaves in Roman Africa during the early Empire (and it is from this period that the analyzed fragment of Vitae Galbae by Suetonius comes from) could perform various official and administrative functions, manage property or even a customs office ${ }^{15}$. They underwent a romanization which concerned not only the outward appearance and language but also, to a large extent, customs and beliefs. Often the process was so far-reaching that it was difficult to

12 D. 14, 3, 20 (Scaevola, Digest, Book V): "Lucius Titius had a freedman appointed to take charge of a money-broker's table, which he was conducting; and the said freedman gave an obligation to Gaius Seius in these words: »Octavius Terminalis transacting the business of Octavius Felix to Domitius Felis, Greeting. You have a thousand denarii in the bank of my patron, which I shall be bound to pay you the day before the Kalends of May«. The question arose whether Lucius Titius having died without an heir, and his property having been sold, Terminalis could lawfully be sued on account of this letter? The answer was that he was not legally bound by these words, nor was there any ground of equity on which he could be sued; as he wrote this in the performance of his duty as a business agent, for the purpose of maintaining the credit of the bank" (The Digest or Pandects of Justinian, transl. S.P. Scott, Cincinnati 1932).
13 A. Bürge, op. cit., p. 472.
14 J. Krzynówek, op. cit., p. 185.
15 M. Pawlak, op. cit., p. 56. 
distinguish a slave from a free person (difficile dignosci potest liber homo a servo) ${ }^{16}$, which created the possibility of confusion in trade, or even socio-political circulation ${ }^{17}$. Moreover, since careful work for the benefit of one's master ${ }^{18}$ could be rewarded with freedom, the use of one's professional skills offered slaves a higher social status, for which many worked most of their lives.

The need for slaves to participate in operations carried out in mensa nummularia may be demonstrated by the specificity of the activities provided by nummularia. The statement of Suetonius (Galba 9) regarding the activities carried out by a banker may also raise some doubts of interpretation. Certainly, nummularius punished by Galba conducted operations within mensae nummulariae. In the Polish translation of Suetonius' work, we read that "the banker dishonestly changed money"19 and for that, he was severely punished by cutting off his hands. In lexicons and encyclopedic dictionaries, emphasis is placed on precisely such a translation of the term verso ${ }^{20}$, which had to do with the basic activity of nummularii.

D. 46, 3, 39 (Africanus libro octavo quaestionum): Si, soluturus pecuniam tibi, iussu tuo signatam eam apud nummularium, quoad probaretur, deposuerim... ${ }^{21}$

The jurist analyzed the case of depositing money with a banker to verify it. Jurisprudence and Roman non-legal literature show this category of bankers through their specific obligations to control the quality of the coin and its exchange ${ }^{22}$. Nummularii conducted their operations in a professional manner in the Forum or other public place ${ }^{23}$. Mensae nummulariae were located near the temples to which their potential clients made pilgrimages, as well as in other public places due to the specific nature of their banking activities.

Nummularii examined the nobility of the metal from which the coins were made and determined the value of minted gold and silver coins ${ }^{24}$. They were also

16 D. $18,1,5$.

17 B. Łapicki, Poglądy prawne niewolników i proletariuszy rzymskich, Łódź 1955, p. 125.

18 Cic. Phil. 8, 11, 32.

19 Gajus Swetoniusz Trankwillus, Żywoty cezarów, transl. J. Niemirska-Pliszczyńska, WrocławWarszawa-Kraków-Gdańsk-Lódź 1987, p. 273.

20 F. Bobrowski, Słownik łacińsko-polski = Lexicon latino-polonicum, vol. 2, Wilno 1822, szp. 1911; T. Dydyński, Słownik łacińsko-polski do źródeł prawa rzymskiego, Warszawa 1890, p. 716.

21 D. 46, 3, 39 (Africanus, Questions, Book VIII.): "If, being desirous of paying the money, I deposit it by your direction with an assayer to be tested..." (The Digest or Pandects...).

22 Petr., Sat. 56, 3; Marc., Epigr. 12, 57, 7; Suet., Vita divi Augusti 4, 4; Apul., Met. 4, 9, 5; Apul., Met. 10, 9, 3. Cf. P. Niczyporuk, Bankierzy publiczni w źródłach prawa rzymskiego, ,Zeszyty Prawnicze" 2014, no. 14, p. 127 ff.

23 See P. Niczyporuk, Bankierzy i operacje bankierskie..., p. $37 \mathrm{ff}$.

24 D. 2, 13, 9, 2; D. 2, 14, 47, 1; D. 14, 3, 20; D. 16, 3, 7, 2; Suet., Vita divi Augusti 4, 4. G. Manna (Degli argentarii in diritto romano, Lanciano 1886, p. 20) claimed that nummularii were originally involved in the exchange of money. It was noted by C. Ferrini in the review of this work ([in:] Opere 
trying to change high-value coins into lower-value ones, i.e. to exchange gold for silver or bronze. Their main occupation beyond quality control was the exchange of money in circulation ${ }^{25}$. During their minting and testing activities, they used qualified personnel recruited from among lower social strata, mainly slaves. The professional examination of the quality of the coin required a great deal of specialist work. Nummularii had to use their professional skills especially when checking silver based on its sound. Before mensa nummularia, tables were set up on which various types of coins were stacked in organized piles and customers were attracted by the calls and buzz of coins. This was to convince passers-by that money would be professionally examined here ${ }^{26}$. The silver coin was repeatedly thrown against the ground or against a piece of marble. But in addition to hearing, other senses - sight, touch, smell - were also involved in this external examination of the material ${ }^{27}$. In this way, it was ensured that it was not filled with other substances, which could have an impact on the value of the coin. The dimensions and type of the coin were also assessed by comparing it with patterns of other coins or samples. It was possible to check whether the coin was minted by the relevant authority ${ }^{28}$. To do this, slaves with the necessary qualifications were used.

In order to determine the value of coins, especially gold, nummularii used test stone ${ }^{29}$. As a result, on their tables there were many instruments, such as trutina two-panel scale for weighing coins ${ }^{30}$. The weight of the coin allowed to assess whether it was not worn out or scrapped, and could therefore lose its weight ${ }^{31}$. The procedures used to examine the authenticity of money after it had been deposited with a prober (nummularius) were quite complicated. The coins, checked by sight, touch and hearing, were put on the scale to verify compliance with the reference weight, and finally counted. For the latter, a plaque (commonly known as abaco)

di Contardo Ferrini, vol. 3: Studi vari di diritto romano e moderno (sulle Obbligazioni, sul Negozio giuridico, sulle Presunzioni), Milano 1929, p. 497). Cf. Laum, Banken, „RE“1924, Supplementband IV, szp. 72; Ch. Gabrielli, Moneta e fi nanza in età repubblicana, Roma 2012, p. 100.

${ }^{25}$ See M. Grant, The pattern of coinage in the early Principate, [in:] Essays in Roman Coinage Presented to Harold Mattingly, Oxford 1956, pp. 102-112.

${ }^{26}$ Mart., Epigr. 12, 57, 7. See also J. Andreau, La vie financière ..., p. 475 ff.

27 Epict., Entr. 1, 20, 8-9.

${ }_{28}$ P. Niczyporuk, A. Talecka, 'Nummularii' jako strażnicy jakości monety w starożytnym Rzymie, [in:] Psucie pieniadza w Europie Środkowo-Wschodniej od antyku po czasy współczesne. Białoruś - Litwa - Eotwa - Polska - Stowacja - Ukraina. Materiaty z VI Międzynarodowej Konferencji Numizmatycznej, Warszawa 2006, pp. 23-30.

29 Teocr. Idyll. 12, 36-37; Plin. Hist. Nat. 33, 126. See also R. Bogaert, L'essai des monnaies dans l'Antiquité, «RBN» 1976, no. 122, p. 5 ff.; S. Balbini De Caro, La banca a Roma, Roma 1989, p. 46.

${ }_{30}$ CIL. VI, 9706. See also E. Bernareggi, Familia monetalis, «NAC» 1974, no. 3, p. 181, n. 14; S. Balbini De Caro, op. cit., p. $46 \mathrm{ff}$.

31 A. Gara, Posdiagrahomena e circolazione monetaria, Milan 1976, pp. 15-124; J. Andreau, Banking and Business in the Roman World, Cambridge 2004, p. 36 and the literature cited therein. 
with a series of identical circular holes was used for placing coins ${ }^{32}$. The research was to make sure that the money checked had the right weight, was made of good alloy, which proved its authenticity. After the test, the purse with the checked coins was sealed with a bone or ivory "card", called tessera nummularia ${ }^{33}$. It was used to protect the money tested against possible replacement or theft.

Tesserae nummulariae are rectangular labels made of ivory most often with inscriptions on all four sides ${ }^{34}$. They were used in mensa nummularia to certify the amount or quality of coins in the money sack ${ }^{35}$. They had quite a standard shape ${ }^{36}$. Tesserae nummulariae had a rounded head and were fitted with a hole in their upper part. It was used by bankers to attach the card to a money sack with a rope. Tesserae nummulariae contained basic information on each of the four sides that made it possible to identify the contents of a particular purse. There we find the name of the slave or freedman who controlled the attached sum, the name of his master or patron, the word spectavit or abbreviation spect. or $s p$. as well as the day, month and year suggested by the relevant consular pair ${ }^{37}$. On most of the preserved tesserarum nummulariarum dating back to $96 \mathrm{BC}-88 \mathrm{AD}$ we have a similar or even identical content of inscriptions ${ }^{38}$. The content of tesserae nummulariae may be an indication that the test operations were carried out by slaves and that they

32 S. Balbini De Caro, op. cit., p. 46.

${ }^{33}$ Large quantities were discovered during archaeological work. See F.M. Heichelm, Storia economica del modo antico, Bari 1972, p. 1014; J. Andreau, La vie financière ..., p. 486 ff.; S. Balbini De Caro, op. cit., p. 52.

${ }^{34}$ About tesserae nummulariae see M. Cary, Tesserae gladiatoriae sive nummulariae, "Journal of Roman Studies" 1923, vol. 13(1-2), pp. 110-113; E. Diehl, Altlateinische Inschriften, Berlin 1964, p. 83; F. Beyer, Geldpolitik in der Römischen Kaiserzeit. Von der Währungsreform des Augustus bis Septimius Severus, Wiesbaden 1995, p. 58; M. Giovagnoli, IV, 4. Tessera nummularia, [in:] Terme di Diocleziano. La collezione epigrafica, eds. R. Friggeri, M.G. Granino Cecere, G.L. Gregori, Milan 2012, p. 205; P. Calabria, F. Di Jorio, Una tessera nummularia dal Palatino in Roma, [in:] Preatti del I Workshop Internazionale di Numismatica. Numismatica e archeologia. Monete, stratigrafie, contesti: dati a confronto, ed. G. Pardini, Rome 2011, pp. 2-14; K. Butcher, M. Ponting, The Metallurgy of Roman Silver Coinage: From the Reform of Nero to the Reform of Trajan, Cambridge 2014, p. 69; A. Buonopane, Tesserae nummulariae da Modena e dal territorio, [in:] Mutina splendidissima. La città romana e la sua eredità, eds. L. Malnati, S. Pellegrini, F. Piccinini, Rome 2017, pp. 219-220.

${ }_{35}$ R. Herzog, Nummularius, „RE“ 1937, no. 17-2, coll. 1415-1455; F. Serrao, Impresa e responsabilità a Roma nell'età commerciale, Pisa 1989, p. 27; J. Andreau, La vie financière..., p. 501; A. Petrucci, 'Mensam exercere'. Studi sull'impresa finanziaria ..., p. 267, n. 50.

${ }^{36}$ R. Herzog, Aus der Geschichte des Bankwesens im Altertum. Tesserae nummulariae, Giessen 1919, p. 19.

37 J. Andreau, Deux tessères nummulaires inédites, « Revue Numismatique » 2001, no. 157, pp. 329-336.

${ }_{38}$ See F. Di Jorio, Una tessera nummularia dal Palatino in Roma, [in:] Numismatica e archeologia. Monete, stratigrafie, contesti: dati a confronto. Workshop Internazionale di Numismatica, eds. G. Pardini, N. Parise, F. Marani, Rome 2018, pp. 158-168; A. Buonopane, Una tessera nummularia inedita in un manoscritto di Francesco Bianchini (1662-1729), [in:] Litterae magicae. Studies in 
had actual knowledge of the content of the controlled purses. It can be stated with a great deal of certainty that, in the course of control activities, these very servi could have committed abuses or even criminal acts. It was this qualified staff that carried out the verification of the money deposited in mensa nummularia. Thus, all irregularities and criminal acts could be committed by slaves verifying the coins by performing control and checking activities. For these acts, they had to bear appropriate punishments.

The penalty of cutting (chopping) off hands was applied to a person who dishonestly changed money, together with an additional disgrace in the form of nailing them to a table, at which this banking activity was carried out. The penalty was adequate only for a person from lower social strata. This persistent violation of a slave's bodily integrity may justify such a severe criminal sanction. Chopping off hands and nailing them to mensae will have a deterrent effect and will reflect the nature of the deed committed by a person who dishonestly changes money. The slave would therefore suffer a well-deserved and adequate punishment, while the sanction applied by emperor Galba may have been the one directly addressed to the person who dishonestly changed money.

\section{REFERENCES}

\section{Translations of sources}

Suetonius, Lives of the Twelve Caesars, Servius Sulpicius Galba, transl. H.M. Bird, Kent 1997. Gajus Swetoniusz Trankwillus, Żywoty cezarów, transl. J. Niemirska-Pliszczyńska, Wrocław-Warszawa-Kraków-Gdańsk-Lódź 1987.

The Digest or Pandects of Justinian, transl. S.P. Scott, Cincinnati 1932.

\section{Literature}

Alföldi G., Historia społeczna starożytnego Rzymu, Poznań 1998.

Andreau J., Banking and Business in the Roman World, Cambridge 2004.

Andreau J., Deux tessères nummulaires inédites, « Revue Numismatique » 2001, no. 157.

Andreau J., Financiers de l'aristocratie à la fin de la République romaine, [in:] Le dernier siècle de la Republique romaine et l'époque augustéenne, Strasbourg 1978.

Andreau J., La vie financière dans le monde romain. Les métiers des maniers d'argent (IV e siècle au J.C. - III e siècle ap. J.C.), Roma 1987.

Andreau J., Les comtes bancaires en nature, «Index » 1987, no. 15.

Balbini De Caro S., La banca a Roma, Roma 1989.

Honour of Roger S.O. Tomlin, vol. 2, Zaragoza 2019, pp. 103-108; R. Martín-Hernández, More than a Logos. The I $\omega \varepsilon \rho \beta \eta \theta$ Logos in Context, [in:] Litteraemagicae..., pp. 187-210. 
Bernareggi E., Familia monetalis, « NAC» 1974, no. 3.

Beyer F., Geldpolitik in der Römischen Kaiserzeit. Von der Währungsreform des Augustus bis Septimius Severus, Wiesbaden 1995.

Bobrowski F., Stownik tacińsko-polski = Lexicon latino-polonicum, vol. 2, Wilno 1822.

Bogaert R., L'essai des monnaies dans l'Antiquité, « RBN» 1976, no. 122.

Buonopane A., Tesserae nummulariae da Modena e dal territorio, [in:] Mutina splendidissima. La città romana e la sua eredità, eds. L. Malnati, S. Pellegrini, F. Piccinini, Rome 2017.

Buonopane A., Una tessera nummularia inedita in un manoscritto di Francesco Bianchini (16621729), [in:] Litterae magicae. Studies in Honour of Roger S.O. Tomlin, vol. 2, Zaragoza 2019.

Butcher K., Ponting M., The Metallurgy of Roman Silver Coinage: From the Reform of Nero to the Reform of Trajan, Cambridge 2014.

Bürge A., Fiktion und Wirklichkeit: Soziale und rechtliche Strukturen des römischen Bankwesens, „ZSS“ 1987, no. 104.

Calabria P., Di Jorio F., Una tessera nummularia dal Palatino in Roma, [in:] Preatti del I Workshop Internazionale di Numismatica. Numismatica e archeologia. Monete, stratigrafie, contesti: dati a confronto, ed. G. Pardini, Rome 2011.

Cary M., Tesserae gladiatoriae sive nummulariae, "Journal of Roman Studies" 1923, vol. 13(1-2).

Chico R.H., Función y origen de los 'Argentarii', "Anuario de Estudios Sociales y Juridicos” 1977, no. 6.

Di Jorio F., Una tessera nummularia dal Palatino in Roma, [in:] Numismatica e archeologia. Monete, stratigrafie, contesti: dati a confronto. Workshop Internazionale di Numismatica, eds. G. Pardini, N. Parise, F. Marani, Rome 2018.

Diehl E., Altlateinische Inschriften, Berlin 1964.

Dydyński T., Stownik łacińsko-polski do źródet prawa rzymskiego, Warszawa 1890.

Ferrini C., rec. [in:] Opere di Contardo Ferrini, vol. 3: Studi vari di diritto romano e moderno (sulle Obbligazioni, sul Negozio giuridico, sulle Presunzioni), Milano 1929.

Fijałkowska L., O przydatności mediewistyki prawniczej dla studiów nad historia prawa starożytnego Bliskiego Wschodu, „Studia z Dziejów Państwa i Prawa Polskiego” 2009, no. 12.

Gabrielli Ch., Moneta e fi nanza in età repubblicana, Roma 2012.

Gara A., Posdiagrahomena e circolazione monetaria, Milan 1976.

Giovagnoli M., IV, 4. Tessera nummularia, [in:] Terme di Diocleziano. La collezione epigrafica, eds. R. Friggeri, M.G. Granino Cecere, G.L. Gregori, Milan 2012.

Grant M., The pattern of coinage in the early Principate, [in:] Essays in Roman Coinage Presented to Harold Mattingly, Oxford 1956.

Heichelm F.M., Storia economica del modo antico, Bari 1972.

Herzog R., Aus der Geschichte des Bankwesens im Altertum. Tesserae nummulariae, Giessen 1919.

Herzog R., Nummularius, „RE“ 1937, no. 17-2.

Jońca M., Przestępstwo znieważenia grobu w rzymskim prawie karnym, Lublin 2013.

Kamacewicz W., Instytucja kary śmierci od starożytności po średniowiecze - wybrane kraje i kodyfikacje, „Kortowski Przegląd Prawniczy” 2017, no. 2.

Keay S.J., Roman Spain, California 1988.

Krzynówek J., Odpowiedzialność przedsiębiorcy (exercitor) w prawie rzymskim, Warszawa 2000.

Laum, Banken, „RE“ 1924, Supplementband IV.

Łapicki B., Poglady prawne niewolników i proletariuszy rzymskich, Łódź 1955.

Maciejewski T., Historia powszechna ustroju i prawa, Warszawa 2007.

Mangas Manjarrés J., Esclavos y libertos en la España romana, Salamanca 1971.

Manna G., Degli argentarii in diritto romano, Lanciano 1886.

Martín-Hernández R., More than a Logos. The I $\omega \varepsilon \rho \beta \eta \theta$ Logos in Context, [in:] Litterae magicae. Studies in Honour of Roger S.O. Tomlin, vol. 2, Zaragoza 2019. 
Maselli G., 'Argentaria'. Banche e banchieri nella Roma repubblicana. Organizzazione prosopografia terminologia, Bari 1986.

Müller D.H., Die Gesetze Hammurabis und ihr Verhältnis zur Mosaischen Gesetzgebung, sowie zu den XII Tafeln, Wien 1903.

Niczyporuk P., Bankierzy i operacje bankierskie w starożytnym Rzymie, Białystok 2013.

Niczyporuk P., Bankierzy publiczni w źródłach prawa rzymskiego, „Zeszyty Prawnicze” 2014, no. 14.

Niczyporuk P., Kilka uwag o karze mutylacyjnej wykonanej wobec rzymskiego bankiera (na marginesie Vita Galbae 9), „Zeszyty Prawnicze” 2019, no. 19.1.

Niczyporuk P., Talecka A., 'Nummularii' jako strażnicy jakości monety w starożytnym Rzymie, [in:] Psucie pieniadza w Europie Środkowo-Wschodniej od antyku po czasy wspótczesne. Białoruś - Litwa - Łotwa - Polska - Stowacja - Ukraina. Materiały z VI Międzynarodowej Konferencji Numizmatycznej, Warszawa 2006.

Niczyporuk P., Talecka A., Rzymska antyczna bankowość wspólnym dziedzictwem Europy, [in:] Pieniadz - symbol - władza - wojna - wspólne dziedzictwo Europy, Białoruś - Estonia - Litwa - Łotwa - Polska - Rosja-Rumunia-Stowacja-Ukraina, Studia i materiaty, ed. K. Filipow, Augustów-Warszawa 2010.

Nowicka D., Nowicki S., Prawo boskie i prawo ludzkie. Sadownictwo starożytnego Izraela na tle praktyki mezopotamskiej, „Scripta Biblica et Orientalia” 2009, no. 1.

Pawlak M., Niewolnicy prywatni w rzymskiej Afryce w okresie wczesnego Cesarstwa, Wrocław 2002.

Peńalver Rodriguez M.A., La banca en Roma, [in:] Estudos en Homenaje al Profesor Juan Igliesias, eds. J. Roset Esteve, J. Iglesias Santos, vol. 3, Madrid 1988.

Petrucci A., 'Mensam exercere'. Studi sull 'impresa finanziaria romana (II sec. a. C. - età del III sec. d.C.), Napoli 1991.

Petrucci A., Qualche riflessione sulla possibile configurazione di un 'diritto bancario 'romano nell'età commerciale (età del III secolo a.C. - età del III secolo d.C.), "Studi Senesi" 2005, no. 15.

Ryś K.D., Historia kary śmierci do końca I połowy XX wieku. Wybrane zagadnienia, „Kortowski Przegląd Prawniczy" 2012, no. 1.

Serrao F., Impresa e responsabilità a Roma nell'età commerciale, Pisa 1989.

Sójka-Zielińska K., Drogi i bezdroża prawa, Wrocław 2000.

Taubenschlag R., Rzymskie prawo prywatne na tle praw antycznych, Warszawa 1955.

Westbrook R., Studies in Biblical and Cuneiform Law, Paris 1988.

\section{STRESZCZENIE}

Gaius Swetoniusz w Vitae Galbae w ramach swoich Vita divi Augusti opisał przypadek osoby zajmującej się działalnością bankierską (nummularius) oraz sankcję penalną zastosowaną wobec niej przez późniejszego cesarza Galbę. Namiestnik prowincji Hiszpania Tarrakońska rozkazał obciąć ręce bankierowi nieuczciwie zmieniającemu pieniądze. By pokazać jeszcze większą surowość nakazanej kary, zarządził przybicie obciętych rąk do stołu, na którym ów bankier dokonywał nieuczciwych działań. Niewątpliwie ukarany przez Galbę nummularius prowadził operacje w ramach mensa nummularia. Właściciele kantorów do wykonania operacji menniczo-probierczych posługiwali się wykwalifikowanymi osobami rekrutującymi się z niższych warstw społecznych, głównie niewolników. Profesjonalne badanie jakości monety wymagało wielu czynności specjalistycznych. Skazany brał udział w czynnościach bankierskich jako pomoc techniczna. Operacje menniczo-probiercze kończyły się opieczętowaniem sakiewki przy pomocy tesserae nummulariae. Takich specjalistycznych działań nie wykonywali obywatele rzymscy. Zawartość tesserae nummulariae może wskazywać na to, że czynności probierczych dokonywali niewolnicy. Servi posiadali faktyczną wiedzę o zawartości kontrolowanych sakiewek, a proces kontroli mógł być okazją do nadużyć czy wręcz czynów karalnych. 
Pobrane z czasopisma Studia Iuridica Lublinensia http://studiaiuridica.umes.pl Data: 26/04/2023 15:54:52

Niewolnik poniósłby więc zasłużoną i adekwatną karę w postaci odrąbania rąk i ich przybicia do stołu, przy którym nieuczciwie dokonywał czynności menniczo-probierczych.

Slowa kluczowe: Galba; bankier, nummularius; lex; niewolnik; sankcja mutylacyjna; mutilatio; mensa nummularia; zmieniać pieniądze; badanie jakości monety; operacje menniczo-probiercze; wartość monety 